\section{Improvement of Survival and Subsequent Growth of Tea Cuttings}

\author{
Jee-Song Chen \\ Taiwan Tea Experiment Substation, Sun Moon Lake, Taiwan \\ Fang-Ming Thseng \\ Taiwan Tea Experiment Station, Yangmei, Taoyuan, Taiwan
}

W.H. Ko

Department of Plant Pathology, Beaument Agricultural Research Center, University of Hawaii, Hilo, HI 98720

Additional index words. Camellia sinensis, benomyl, stock plant, rooting

Abstract. Stock plants of tea [Camellia sinensis (L.) Kuntze cv. Chin-shin Oolong] were sprayed three times at weekly intervals with benomyl before taking cuttings. The survival rate of cuttings was increased from $3.3 \%$ in the nontreated controls to $76 \%$ in 1986 and from $6.4 \%$ to $83 \%$ in 1987 . The treatment also greatly improved the subsequent growth of cuttings. Soaking cuttings in benomyl solution before sticking slightly improved survival and subsequent growth of cuttings. Chemical name used: methyl[1-[(butylamino)carbonyl]-1H-benzimidazol-2-yl]carbamate (benomyl).

Tea is an important agricultural product in Taiwan for both export and local consumption. Currently, $\approx 24,500$ ha of tea are grown on the island. About $30 \%$ of the tea grown on plantations is 'Chin-shin Oolong', used for preparation of the popular Oolong tea.

Propagation of tea is accomplished primarily by cuttings. Among the cultivars used in Taiwan, 'Chin-shin Oolong' is the most difficult to propagate because of its susceptibility to brown blight or anthracnose caused by Glomerella cingulata (Stonem.) Spauld. \& Schrenk (Weber, 1973). When rooting of cuttings is carried out during the summer, the survival rate usually is $<10 \%$. Dipping cuttings in a fungicidal suspension of benomyl before sticking in the ground bed for rooting only slightly increases the survival rate. Therefore, rooted cuttings of 'Chin-shin Oolong' have always been in short supply. The objective of this study was to find an

\footnotetext{
Received for publication 6 Feb. 1989. Journal Series no. 3346 of the Hawaii Inst. of Tropical Agriculture and Human Resources. Supported in part by a grant from the Council of Agriculture of the Republic of China. The cost of publishing this paper was defrayed in part by the payment of page charges. Under postal regulations, this paper therefore must be hereby marked advertisement solely to indicate this fact.
}

effective method for improving survival and subsequent growth of tea cuttings.

The treatment consisted of spraying all 4and 5-year-old 'Chin-shin Oolong' bushes grown on the Taiwan Tea Experiment Station farm with $500 \mathrm{ml}$ benomyl 50\% WP (Benlate) at 500 ppm in July 1986 and 1987. Benomyl spray was applied three times at 7day intervals, and cuttings were made on the 4th week. Control plants were similarly sprayed with water. Single-leaf cuttings $(6$ $\mathrm{cm}$ long) were made from stems with a brownish epidermis, which indicates the opfrom tea cultivar Chin-shin Oolong in July 1986 and 1987.

${ }^{2}$ Data were recorded 11 months after planting. timum stage of maturity-for cuttings to root. For the fungicide soaking treatment, cuttings from nontreated bushes were immersed in benomyl suspension at $500 \mathrm{ppm}$ for $1 \mathrm{hr}$. Fifteen cuttings were stuck in a $25-\mathrm{cm}$ clay pot ( $\approx 11$ liters) containing soil not previously used for rooting tea cuttings. Pots were placed on the ground in a screenhouse within a Saran cloth (70\% black Saran shadecloth)covered tunnel $\approx 60 \mathrm{~cm}$ above the ground at the top. Cuttings were watered twice daily. Six pots, each containing 15 cuttings, were used for each treatment and data were recorded after 11 months. The 1986 experiment was repeated in 1987.

When stock plants were sprayed with benomyl before the removal of cuttings, the survival rate of 'Chin-shin Oolong' cuttings was increased from $3.3 \%$ in the controls to $76 \%$ in.1986 and from $6.4 \%$ to $83 \%$ in 1987 (Table 1). The benomyl treatment also significantly affected the subsequent growth of surviving cuttings (Fig. 1). The number of leaves and the length and dry weight of stems and roots were increased $\approx 2$ to 4 fold when compared with nontreated controls in both years. The differences in number of roots were not significant.

When cuttings from unsprayed plants were soaked in benomyl solution before sticking in pots for rooting, the survival rate was increased only from $3.3 \%$ to $8.9 \%$ in 1986 and $6.4 \%$ to $9.5 \%$ in 1987 (Table 1). Effects of the fungicidal dip on subsequent growth of rooted cuttings was relatively small compared to that of cuttings taken from stock plants sprayed with benomyl.

Soaking cuttings in a fungicidal suspension before sticking is a recommended prac-

Table 1. Effect of benomyl application method on survival and subsequent growth of cuttings obtained

\begin{tabular}{|c|c|c|c|c|c|c|c|c|}
\hline Treatment & Year & $\begin{array}{l}\text { Survival } \\
\text { rate } \\
(\%) \\
\end{array}$ & $\begin{array}{l}\text { Leaves } \\
\text { per } \\
\text { cutting } \\
\text { (no.) }\end{array}$ & $\begin{array}{c}\text { Stem } \\
\text { length } \\
(\mathrm{cm})\end{array}$ & $\begin{array}{l}\text { Stem } \\
\text { dry wt } \\
\text { (g) }\end{array}$ & $\begin{array}{l}\text { Root } \\
\text { length } \\
(\mathrm{cm})\end{array}$ & $\begin{array}{l}\text { Root } \\
\text { dry wt } \\
\text { (g) }\end{array}$ & $\begin{array}{l}\text { Roots } \\
\text { per } \\
\text { cutting } \\
\text { (no.) } \\
\end{array}$ \\
\hline $\begin{array}{l}\text { Stock plants } \\
\text { sprayed with } \\
\text { benomyl }\end{array}$ & $\begin{array}{l}1986 \\
1987\end{array}$ & $\begin{array}{l}76 \mathrm{a}^{\mathrm{y}} \\
83 \mathrm{a}\end{array}$ & $\begin{array}{l}13.3 \mathrm{a} \\
17.2 \mathrm{a}\end{array}$ & $\begin{array}{l}18.2 \mathrm{a} \\
20.1 \mathrm{a}\end{array}$ & $\begin{array}{l}0.94 \mathrm{a} \\
1.02 \mathrm{a}\end{array}$ & $\begin{array}{l}28.0 \mathrm{a} \\
30.9 \mathrm{a}\end{array}$ & $\begin{array}{l}0.42 \mathrm{a} \\
0.51 \mathrm{a}\end{array}$ & $\begin{array}{l}12.3 \mathrm{a} \\
13.6 \mathrm{a}\end{array}$ \\
\hline $\begin{array}{l}\text { Stock plants not } \\
\text { sprayed, cuttings } \\
\text { soaked in beno- } \\
\text { myl suspension }\end{array}$ & $\begin{array}{l}1986 \\
1987\end{array}$ & $\begin{array}{l}8.9 \mathrm{~b} \\
9.5 \mathrm{~b}\end{array}$ & $\begin{array}{r}5.0 \mathrm{~b} \\
12.1 \mathrm{~b}\end{array}$ & $\begin{array}{l}12.1 \mathrm{~b} \\
14.0 \mathrm{~b}\end{array}$ & $\begin{array}{l}0.42 \mathrm{~b} \\
0.59 \mathrm{~b}\end{array}$ & $\begin{array}{l}26.8 \mathrm{a} \\
27.8 \mathrm{a}\end{array}$ & $\begin{array}{l}0.13 \mathrm{a} \\
0.16 \mathrm{~b}\end{array}$ & $\begin{array}{l}11.6 \mathrm{a} \\
12.9 \mathrm{a}\end{array}$ \\
\hline $\begin{array}{l}\text { Control, no beno- } \\
\text { myl application }\end{array}$ & $\begin{array}{l}1986 \\
1987\end{array}$ & $\begin{array}{l}3.3 \mathrm{c} \\
6.4 \mathrm{c}\end{array}$ & $\begin{array}{l}3.1 \mathrm{c} \\
6.3 \mathrm{c}\end{array}$ & $\begin{array}{l}5.5 \mathrm{c} \\
4.4 \mathrm{c}\end{array}$ & $\begin{array}{l}0.23 \mathrm{c} \\
0.30 \mathrm{c}\end{array}$ & $\begin{array}{l}14.5 \mathrm{~b} \\
16.5 \mathrm{~b}\end{array}$ & $\begin{array}{l}0.10 \mathrm{~b} \\
0.16 \mathrm{~b}\end{array}$ & $\begin{array}{l}11.4 \mathrm{a} \\
11.6 \mathrm{a}\end{array}$ \\
\hline
\end{tabular}

'For each year, mean separation in columns was based on Duncan's multiple range test, $P=0.05$. 


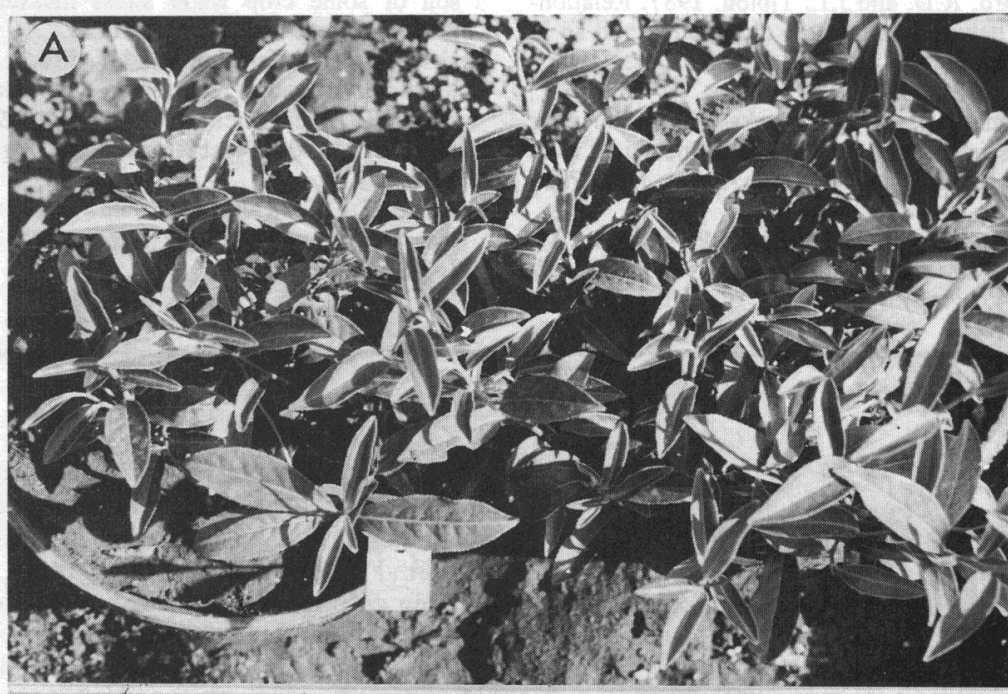

tice for camellias (Baxter, 1982). However, this practice is ineffective for propagating 'Chin-shin Oolong' tea plants due to the sensitivity of this cultivar to G. cingulata and, probably, the ability of the pathogen to cause latent infection. $G$. cingulata has been reported to cause latent infection in a number of hosts (Verhoeff, 1974). Spraying stock plants with the systemic fungicide benomyl before removal of cuttings protects the cuttings from infection and suppresses the pathogen in the latent state. This protection is considered to be the main reason why the problem of poor survival rate of 'Chin-shin Oolong' tea cuttings can be solved by spraying stock plants with benomyl, a systemic fungicide effective against $G$. cingulata (Smith, 1982). The same treatment may be useful for rooting cuttings of other plant species.

\section{Literature Cited}

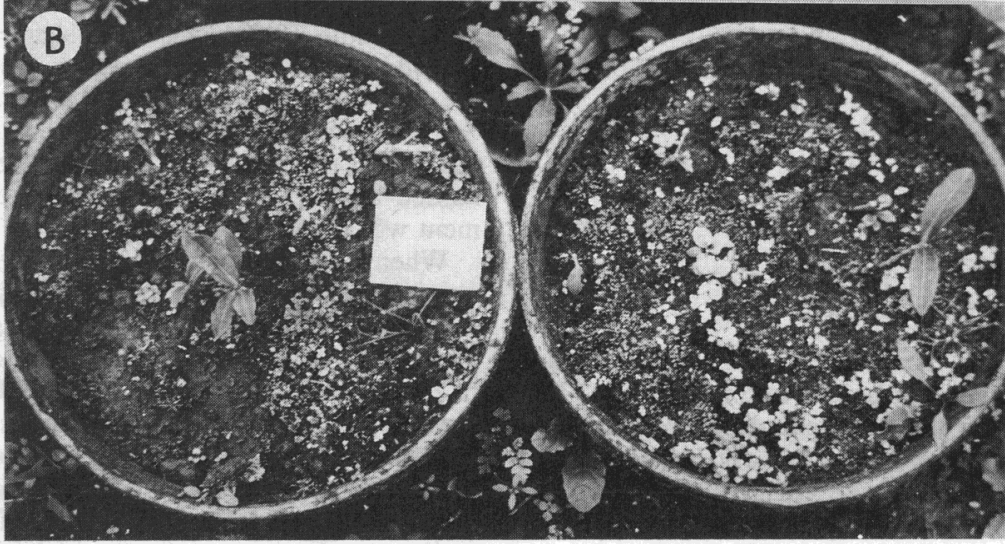

Fig. 1. Survival and growth of 'Chin-shin Oolong' tea cuttings 11 months after planting. (A) Cuttings obtained from stock plants sprayed with benomyl. (B) Control cuttings obtained from nontreated stock-plants. Contents on labels of the experiment are not visible. 